\title{
Philosophical Interactions between "East and West": China, Korea, Europe and the Case of Dasan (Jeong Yak-yong, 1762-1836) ${ }^{1}$
}

Jana S. ROŠKER ${ }^{*}$

\begin{abstract}
Though the Confucian system of thought, society, and government has a long history in Korea, Chinese Confucian scholars, preoccupied with the urgency of "saving the Confucian essence" used only Japan as a reference in Asia. Therefore, the present article aims to introduce Dasan 茶山 (Jeong Yak-yong 정약용, 1762-1836), who was one of the main representatives of Korean Confucian philosophy. It exposes his significance for the full-range understanding of the landscape of this important traditional East Asian stream of thought as well as for the intellectual syntheses between Confucian teachings and the Christian religion. The author analyses Dasan's thought from the Sinological perspective and exposes several elements which represent an elaboration and an upgrading of traditional Chinese Neo-Confucian philosophy.
\end{abstract}

Keywords: Korean Confucianism, Dasan, the School of Practical Learning, silhak, sangje

\section{Izvleček}

Ne glede na dejstvo, da ima konfucijanski idejni, družbeni in politični sistem v Koreji že dolgo zgodovino, so kitajski konfucijanski teoretiki v svojih prizadevanjih za »reševanje esence konfucijanstva« kot azijsko referenco običajno upoštevali zgolj Japonsko. Zato namerava pričujoči članek predstaviti Dasana 茶山 (Jeong Yak-yonga 정약용, 17621836), ki sodi h glavnim predstavnikom korejske konfucijanske filozofije. Izpostavlja njegov pomen za celovitejše razumevanje širokega spektra te pomembne vzhodnoazijske idejne struje in za vzpostavljanje miselnih sintez med konfucijanskimi nauki in krščansko religijo. Avtorica analizira Dasanovo miselnost iz sinološke perspektive in v njej izpostavi vrsto elementov, ki predstavljajo nadgradnjo tradicionalne kitajske neokonfucijanske filozofije.

Ključne besede: korejski konfucianizem, Dasan, Šola praktičnega učenja, silhak, sangje

\footnotetext{
${ }^{1}$ The author is grateful to the Chiang Ching-Kuo Foundation for its generous support of the research underlying the present article.

* Jana S. ROŠKER, PhD, Professor, Department of Asian and African Studies, University of Ljubljana, Slovenia. jana.rosker@ff.uni-lj.si
} 


\section{Introduction}

Although Confucianism originated in China, where it formed the crucial state doctrine for almost two millenniums, Confucian culture is not only limited to the Chinese world, but rather represents a cultural heritage that is commonly shared in the entire East Asian region, including Korea, where Neo-Confucianism was established as the state ideology during the Joseon period (1392-1897). However, unfortunately, in the Chinese project of responding to the challenge of the West, Korea has been almost absent for several decades. Until recently, Chinese scholars who were dealing with the Confucian revival hardly paid any attention to the Korean experience.

The revitalization of the complex traditions of Confucian philosophical thought has assumed increasing relevance and significance in recent decades. In the first half of the $20^{\text {th }}$ century, this tendency could be observed in the works of many of the leading modern Chinese philosophers ( $\mathrm{Tu} 2010$, 13) who were searching for ways to renew the methodological and theoretical aspects of the Chinese tradition, and especially of the pre-modern philosophy, which followed the Neo-Confucian revival.

Such aims are grounded in the conviction that traditional Confucianism, understood as a specifically East Asian social, political and moral system of thought can, if renewed and adapted to meet the conditions of the modern era, serve as the foundation for an ethically meaningful modern life, while also providing a spiritual antidote to the alienation which became increasingly visible as a collateral effect of the capitalistic glorification of competition and the singleminded pursuit of profit.

The revitalization of the Confucian tradition remains one of the most important theoretical currents in contemporary East Asian theory. Due to its potentially stabilizing social function and its harmonious compatibility with capitalism, many scholars ${ }^{2}$ see it as the Asian equivalent of Max Weber's "protestant ethic". In modern Sinology, this view is known as the "post-Confucian hypothesis":

Indeed, many scholars have invoked Confucianism as an important cultural cause of East Asia's economic success. In particular, scholars such as Berger and Tu have gone so far as to propose what is called the post-Confucian thesis, i.e.: that Confucianism has not only facilitated economic development in East Asian countries, but also has enabled these countries to create a different kind

\footnotetext{
${ }^{2}$ For example, see Feng Yaoming 1992, 227; Wang Hui 2000, 40.
} 
of capitalism and take a different path to modernity than the West (Kwon 2007, 55).

Hence, it is by no means coincidental that issues connected to the Confucian revival belong to the most important tasks in contemporary research in the field of classical Chinese philosophy. However, when dealing with these issues, it becomes increasingly clear that Confucian culture is not only limited to the Chinese world, but also represents a cultural heritage that is commonly shared in the entire East Asian region. Thus, it is easily understandable that numerous modern Confucians have repeatedly exposed the importance of studying and researching the multifarious elaborations and developments of Confucian philosophy and ethics deriving from other East Asian regions, as for instance Japan and Korea. In his article entitled Korean Confucianism from a Sinic perspective, Tu Weiming points out:

I propose that a dialogue among civilizations focusing on the core values is necessary for human survival and flourishing in Confucian East Asia. The philosophical enterprise to identify the "universal ethic" must be broadened by thick descriptions of paths of learning to be human in the Confucian cultural sphere. The danger of shared vulnerability as well as the hope of shared aspiration impels us to move beyond unilateralism in order to work toward a dialogical civilization. ( $\mathrm{Tu} 2010,13)$

In this context, we can mention another modern Chinese scholar, Lee Hong-jung, who describes the potential of the Confucian tradition in terms of its constitutive role within the concept of so-called "Asian values":

Characteristic Asian values were transmuted into state-led economic models, playing a significant role in the economic development of Asian countries. Familism promoted strong cooperation among blood relatives, and created small- and mid-size family businesses based on Confucian familism and family ethics. These family businesses gradually developed to become the framework of Asian capitalism. Community spirit is also a key Asian value. By maintaining strong ties based on community spirit and solidarity, Asian populations have contributed to the economic development of the region. Promoting education, the most important Asian value, also stems from Confucianism which teaches that it is better to educate one's children than to give them wealth. This tenet has helped pave the way to economic development. The emphasis on education has also raised management capabilities and technological expertise, and has facilitated economic development through improved productivity (Lee Hong-jung, 2003, 32). 
However, as already mentioned, in the East Asian project of responding to the challenge of the West, in the Chinese and, to a certain degree, in the Japanese scholarship as well, Korea has been more or less absent. Until know, Chinese Confucian scholars, preoccupied with the urgency of "saving the Confucian essence" only used Japan as a reference in Asia. They hardly paid any attention to the Korean experience ( $\mathrm{Tu} 2010,13)$. The first generation of the Confucian revival since the May Fourth Movement (1919-1949) does not seem to consider Korea relevant to their concerted effort to learn science and democracy from the West. In the second generation (1949-1979), Wing-tsit Chan studied Yi T'oegye's interpretation of Zhu Xi's thought. His primary purpose was to judge the adequacy of Yi's understanding of Master Zhu. Tang Junyi was intrigued by the so-called "two schools" of Zhu Xi in the Korean Confucian tradition, but he was not motivated to study the phenomenon. Qian $\mathrm{Mu}$ also made reference to Korean Confucianism, but generally it was quite superficial.

I will try to illustrate my point by introducing some aspects of Jeong Yakyong's Neo-Confucian philosophy. Each requires focused investigation. Together, they should present a persuasive argument for taking Korean Confucianism absolutely seriously for East Asian, especially Chinese, Confucian scholars. It should become obvious that an informed appreciation of Confucianism in Korea will enrich the self-understanding of East Asian Confucianism and, more pertinently to the present discussion, be essential for comprehending the full-range of the landscape of Chinese Confucianism.

The present article explores traditional Korean Confucian thought from a Sinic perspective, i.e. through analyses and critical evaluations of its Chinese and/or Sinological interpretations.

\section{Historical and Methodological Background}

The Confucian system of thought, society, and government has a long history in Korea. Many think that since the fourteenth century, Confucianism and Korea were so closely intertwined that Korean history could not be understood without Confucianism while the study of Confucianism itself can be substantially enriched by resort to its Korean experience.

According to most researchers, knowledge of some of Confucian teachings can be traced in the earliest days of our real knowledge of the peninsula. The country has a long history as a civilized and literate land, with the first dynasty starting 
about 57 BC. In the early years, Confucianism existed side-by-side with other religions and ways of life. For many centuries, its influence on Korea was continuous but not pervasive. With the fourteenth and fifteenth centuries, however, its influence on government and society began to be decisive and, especially from the sixteenth century on, it dominated almost completely the thought and philosophy of the peninsula, continuing to do so until the opening of the present century. In the present article, however, we will not focus upon the historical, social and political connotations of Confucian teachings in Korea, but rather examine and introduce its philosophical dimensions.

Neo-Confucian philosophy can be regarded as the discourse, which had the most profound influence upon traditional Korean thought (Yoo 2013, 181). NeoConfucianism originated in China with Han Yu (768-824) and Li Ao (772-841) in the Tang Dynasty, and Zhu Xi (1130-1200) in the Song Dynasty became one of its most famous exponents. Neo-Confucians were important because they began to provide rational grounds for the standards established by ancient Confucian philosophers and to explain why they should be followed. According to Yoo Weon-ki $(2013,182)$, Korean Neo-Confucians in the sixteenth century in the Chosön Dynasty became even more precise and careful about supplying rational and systematic grounds for their claims. Good examples of such writing methods can be found in the so- called Four-Seven Debate between Ki Tae-sùng (高峯 Kobong, 1527-1572) and Yi Hwang (李滉, T'oegye, 1501-1570). Their arguments were profound and based upon rational and logical grounds. However, most Korean Neo-Confucians do not seem to be interested in taking a logical approach to Neo-Confucian discourses. Instead, they tend to remain focused upon summarizing and interpreting the crucial ideas and viewpoints of the past (i.e. mostly Chinese) Neo-Confucian philosophers without critically analyzing, or evaluating their positions. Besides, they were not very interested in judging the validity of the arguments. Probably the reason for such writing methods lies in the fact that they were not familiar with such methods providing consistency, validity, and conceptual clarification. (Yoo 2013, 191) In the fields of metaphysics, sociopolitical philosophy and cosmology, however, Korean Neo-Confucian philosophers have contributed a lot to the world philosophy by exposing many aspects which are topical and most relevant even for the present day philosophy. Here, we could mention the Korean Neo-Confucian scholar Yi Yulgok (李珥 1536-1584) who believed that the universe could not be completely comprehended by human intelligence or through human thought processes alone. 
Yulgok believed that the universe is a "mystery" which can and should not be reduced to the rational or conceptual framework of human cognitive system. His work is doubtless a rich resource for inspiration in recognizing and rediscovering the cosmological dimension of Korean Neo-Confucianism, for he developed an eco-cosmology, which emphasized the inter-relationship of men and the universe (Ro 2012, 122). This new eco-cosmology can be regarded as a basis for understanding ecological issues from the cosmological perspective.

Along with the abovementioned scholars, Dasan ${ }^{3}$ (Jeong Yak-yong, 17621836) is usually listed among the greatest Confucian philosophers in all Korean history. In the following, I will try-through a critical analysis of Chinese Confucian interpretations of his work-to introduce, summarize and evaluate his main contributions to the development of intercultural dimensions of Confucianism.

\section{Dasan (Jeong Yak-yong, 1762-1836): His Life and Work}

Jeong Yak-yong (1762-1836), more widely known under his pen-name Dasan (茶 山) is regarded in South Korea today as one of pre-modern Korea's best philosophers. His mains works are dealing with explorations of Neo-Confucian themes. He is considered as one of the greatest thinkers of the later Joseon period, for he wrote highly influential books on philosophy, science and theories of government. He was also famous for his poetry. Dasan's philosophical position is mostly identified with the Silhak (practical learning, 實學) school. As we shall see, he also delivered important contributions in the field of intercultural syntheses, namely between the Neo-Confucian and the Christian thought.

During his lifetime, he held significant administrative positions and was even a close confident of King Jeongjo who ruled in the period from 1776 till 1800. This close relation has begun in 1784, when the king was deeply impressed by the objectivity and intelligence of Dasan's replies to a set of questions he had formulated. One year before, Dasan has already passed the chinsagwa (literary licentiate examination), which allowed him to enter the Seonggyungwan (成均館 National Confucian academy). In 1788, Dasan took top place in the daegwa (higher civil service exam) and was offered a position in the Office of Royal Decrees. However, because he belonged to the progressive 'Southerner fraction'

\footnotetext{
${ }^{3}$ In different transcriptions, his name is also spelled Tasan. 
(Namin) of Korean Confucianism, he was seen as an enemy by the members of the opposing "Old Doctrine fraction". The conflict between them has developed into royal intrigues, which led to Dasan's expulsion; as a result, he was forced to spend eighteen years (from 1801 till 1818) in exile in Gangjin, a town in the South Jeolla province. His opponents have grounded their accusations on his "revolutionary Western influences", for he was allegedly not only researching and spreading the thoughts and methods of Practical Learning (which was introduced to China from Europe $)^{4}$, but also some ideas of Roman Catholicism itself. This presumption was not merely based on his philosophical thoughts, but also on the fact that his elder brother was openly Catholic.

Although Dasan was probably never baptized, he also showed a positive attitude toward the Western religious system. His ideas were doubtless influenced by this system, for otherwise it would be hard to explain why God and the spirits occupy an important position in his classical writings. In this context, however, is worth noting that Dasan's understanding of Western learning was still mainly based on the re-interpretation of the Chinese Neo-Confucianism; it was not grounded upon a form of faith that could bring the Western institutional factors such as church into the Confucian society of that time (Cawley 2012, 30). By understanding and absorption of such learnings, Dasan obviously tried to systemize Confucian thought. These methodological efforts have led to the establishment of a new theoretical reference framework and have thus played a very important role in the further development of Confucian philosophy in Korea.

Hence, it is not coincidental that Dasan is still considered by Koreans as a cross-cultural philosopher, and that his work is serving as an example of how Koreans can borrow from the West while nonetheless remaining authentically Korean (Baker 2013, 41).

Dasan has namely modified traditional Korean Confucian moral philosophy to include notions of human nature and desires rather than innate virtue, the importance of free will rather than mere determination, and the existence of a Sangje (上帝, Highest Lord) as a necessary incentive to proper behavior (Baker 2013, 41). Though he supported these changes to traditional Korean Confucian

\footnotetext{
${ }^{4}$ However, the relationship of the School of Practical Learning (silhak, 實學) to Neo- Confucianism is also still subject to many theoretical controversies. Problems concerning the question whether it was "imported" from Europe and thus arose in opposition to Neo-Confucianism, or whether it should instead be seen as simply one variety of Neo-Confucianism, are still being debated.
} 
philosophy with references to the Classics and his own personal moral experience, observers have noticed the possibility of Western influence on his thinking. In this context, it is important to note that although Dasan was as a Confucian scholar, his thinking largely also reflected certain characteristics of the Western thought (Baker 2013, 41). These foundations are mainly reflected in his critical theoretical re-interpretations of Confucianism, for he managed to incorporate in its frameworks some crucial new concepts, which will be more detailed explored and introduced bellow.

\section{Metaphysical and Ethical Approaches}

In order to understand the common threat of Dasan's philosophy, it seems necessary to provide a basic approach to his abovementioned understanding of Sangje (Highest Lord) as the ultimate reality (Chung 2006, 254). In the following, we will thus examine the Dasan's theoretical background and his transformation of the Confucian system through his concept of Sangje, because his approach is of utmost significance to the elaborations of the original Neo-Confucian concept of ultimate reality (taiji 太極).

According to Dasan, Sangje governs all beings - nature, deities and menwith providence, transcending them at the same time. Sometimes, it is also called "Heaven" (Gun 1994, 5)

The conceptualization of Sangje was very close to the Western concept of a monotheistic God; Dasan stated explicitly that there was only one Sangje, not two, for he was so noble that he had no counterpart (Dasan in Gun 1994, 14). This theological idea was probably stimulated by his encounter with Catholicism in his youth. Unlike to the classical Chinese Neo-Confucian philosophers, who thoroughly followed Mengzi's philosophy of innate goodness, Dasan did not believe humans were instinctively virtuous. Since as a result, we cannot even trust our minds to always tell us the right way to behave. To solve this moral dilemma, Dasan came up with an untraditional answer, grounded in his untraditional reading of the Confucian Classics (Baker 2013, 49). He believes that we need to be "shamed into doing the right thing" (Baker 2013, 49), for the only way we can be sure that we will be ashamed every time we do something wrong is if we keep in mind that, always and everywhere, we are being watched to see if we think and act properly. "Who can possibly watch us always and everywhere? There is only one 
possible answer: the Lord Above, whom he called by the ancient Confucian name Sangje 上帝.” (Baker 2013, 49)

But Dasan's Sangje also possessed an ontological dimension (Dasan 1974, 34). Dasan has namely regarded all natural phenomena as products of two potentials that could be compared to spiritual and material substances. They represented the ontological basis of human beings. According to Gun Yoo Tae $(1994,16)$ these two substances which ultimately follow Sangje's providence, can be seen as forming dual metaphysics, for in Dasan's thought they represented two origins of existence. The origin of these two substances of which the phenomenal world is composed was Sangje. Thus, in theoretical terms, many scholars (see Gun 1994, 16) define Dasan's metaphysics as a theological dualism, for this Korean NeoConfucian philosopher saw the phenomenal world as being composed of two (material and spiritual) substances, whereas the ultimate reason of existence was represented by Sangje, the only God and the object of religious faith.

Some other scholars, as for instance Li Fenggui $(2005,183)$ expose that Dasan neglected the importance of the spiritual essence $i$ (理) which has been seen by $\mathrm{Zhu} \mathrm{Xi}$ as the primary ontological element. He emphasized the leading role of the material substance $k i$ (氣) which he also equated with the concept of ultimate reality (太極). Thus, his onto-metaphysical system cannot be equated with the idealistic dualism. On the other hand, he also acknowledged the primary role of spirit, for his Sangje in the role of the Supreme Being was seen as the ultimate origin or source of existence; thus, scholars advocating the position, according to which Dasan's system is not dualistic, expose that his metaphysics cannot be regarded as a philosophy based on material dualism.

In my own opinion, Dasan's system can be regarded as a form of idealistic (theological) dualism. In his view, the primary role of matter is namely only referring to the phenomenal world (Dasan 1974, 23); ultimately, both contrasting poles (substances of $i$ and $k i$ ) are unified in the pure spiritual realm of Sangje, forming a trinity which can in conceptual sense be compared with the theory underlying the Christian faith.

The two substances in question originally appeared in the Chinese NeoConfucianism of the Song and Ming Dynasties ( $l i$ 理 and $q i$ 氣). In Chinese NeoConfucianism, however, they appeared as a binary category, in which both antipoles functioned in a complementary relation (see Zhu Xi 2000, 13-34). Hence, 
their unification in a comprehensive, all-embracing entity of a Supreme Being like Sangje and the formation of a trinity represents an innovative element in the NeoConfucian philosophy.

However, Dasan's Sangje was not a creator of the universe (Baker 2013, 53). There is also no heaven or hell in his theism. In essence, his Sangje was still a kind of Confucian (i.e. rather pragmatically conditioned) ultimate reality and his morality was thus a form of Confucian morality ${ }^{5}$. In the methodological or stylistic sense, his arguments were also essentially Confucian, for he remained within the tradition of philosophizing by writing commentaries on the Confucian Classics.

Nevertheless, his argument for the existence of his Confucian God required him to break with his Confucian tradition on several key philosophical issues, starting with the role of $1 \mathrm{i}$ in the cosmos and the definition of human nature (Baker 2013, 54).

As we have seen, Dasan's specific and original synthesis between Western and Neo-Confucian thought becomes most clear in his ethical theories. Similar to the majority of other Confucian philosophers, for Dasan, the most urgent concrete problems were moral problems, especially those regarding the question how to cultivate the ability to act appropriately in every situation. This becomes clearly visible in his treatments of the ethical function of emotion in his annotations of Confucian classics. Defining human nature as "preference" (Baker 2010, 58), Dasan argued that the specific content of nature is to "like good and dislike bad." Verifying the existence of such nature based on his own psychological experiences and the existing canon of literature, he attempted to prove the presence and universality of moral emotions, especially in ordinary dialogue, relying on psychological responses to specific events and the notion of human nature (Baker 2013, 47). He exposed that emotions had to be properly adjusted (Dasan 1974, 19), because identical emotions could lead to contrasting actions, depending on

\footnotetext{
${ }^{5}$ However, we have to take into account several aspects, which cannot be treated in detail in the limited scope of this article. We must not forget, for instance, that the so-called Confucian morality was (or is) by no means a monolithic formation. Since Chinese philosophy follows the ontological model of immanent transcendence, moral postulates possessed innate qualities in the framework of traditional Chinese Confucianism. In other words, the Chinese Confucian morality was something that had to be actively incorporated into the individual moral Self (daode xingti 道德性體) through moral cultivation (xiu shen 修身). Hence, in classical Confucianism, this moral Self assumed the role of the ultimate spiritual substance (which was also endowed with morality). Since the notion of moral Self was obviously either overlooked or neglected by Dasan, it was only an external metaphysical force that could assume the function of an ultimate arbitrary substance governing over and judging individual behavior.
} 
whether or not they tended to "achieve harmony in moderation". In this regard, Dasan stressed the importance of sincerity and proposed that people, as sincere actors, exert every effort for religious cultivation by serving the abovementioned Sangje (Highest Lord, 上帝). Hence, Dasan's theory on emotions offers a basis for empirically elaborating the fundamental problems regarding the problematic popularization of Confucian philosophical ethics, thus, it represents one of the rare contributions to the elaboration of a synthesis between the Neo-Confucian and the Christian thought. Besides, his notion of emotions has significance in shifting philosophical concerns from the metaphysical sphere to the everyday lived world.

\section{Political Thought and Practical Learning}

In Korea, the importation of Neo-Confucian thought brought about profound changes in the religious, philosophical, and social climate of the Koryo kingdom (918-1392) during the time of its decline, forming the foundation for the creation of a new sociopolitical and cultural order under the Choso Dynasty (1392-1910, see Chung 2006, 253). Thus, it is not coincidental that besides his metaphysical and moral theories, Dasan's perhaps most important contribution to the development of pre-modern East Asian thought can be found in his political philosophy, which was based on elaborations of the Neo-Confucian ethics. According to $\mathrm{Zhu} \mathrm{Xi}$, individuals are transformed into moral beings through the cultivation of their character, and the increase of moral individuals therefore leads to the generation of a moral society. While acknowledging that moral success through such cultivation produces moral heroes, Dasan Jeong Yak-yong argued that inner cultivation alone could not produce moral individuals and a moral society because in reality humans have a myriad of conflicting desires and fluctuating volitions. Without confining morality to the purification of inner mind, Dasan considered both inner reflection and external practice grounded on free will to be necessary. Through both, he believed, individuals attain a personal sense of responsibility and preside over the entire process of morality. Although in reality there are personal differences, people can partake proactively in the construction of a moral society. In this regard, Dasan is credited with shifting the focus of Confucianism from the sage and his inner reflection to common people and practice. For him, Confucian politics should be understood as a horizontal relationship between the ruler and the people as captured in the idea of "accompanying people" (與民), rather than a hierarchical one as in the "bestowing of privilege to the people" (爲民) (Chang 2014, 10). 
As explained in the previous section, Dasan placed great emphasis on Sangje in the sense of the Supreme Being controlling and regulating human behavior and forcing men to act in accordance with moral virtues. He agreed, however, that morality was defined in terms of human interactions, rather than interactions with supernatural beings (Baker 2010, 56).

In his exegesis of the term "perfect goodness" in the Great Learning, Tasan argued that "perfect goodness" referred to appropriate interactions between human beings. For Tasan, just as for the Confucians who preceded him, it was significant that a key term which we translate today as morality, illyun, is composed of two Sino-Korean characters which mean "people" and "relationships" respectively. Therefore he could not conceive of morality apart from human relationships. (Baker 2010, 56)

This communitarian aspect is connected to the fact that Dasan was one of the most prominent adherents and creators of the Korean Confucian School of practical learning (silhak, shixue 實學).

This term is usually applied in the sense of a new trend in thought that, stimulated by worsening contradictions in Korean society in the $18^{\text {th }}$ century, focused on concrete social reality rather than abstract philosophical issues and sought to promote reform and therefore it can be said to have a modern and a nationalistic orientation.

According to most scholars, Silhak was designed to counter the "uncritical" following of Confucian teachings and the strict adherence to "formalism" and "ritual" by neo-Confucians. Most of the Silhak scholars were from fractions excluded from power and other disaffected scholars calling for reform. They advocated an empirical Confucianism deeply concerned with human society at the practical level. Its proponents generally argued for reforming the rigid Confucian social structure, land reforms to relieve the plight of peasant farmers, promoting Korea's own national identity and culture, encouraging the study of science, and advocating technology exchange with foreign countries. Silhak scholars wanted to use realistic and experimental approaches to social problems with the consideration of the welfare of the people. Silhak scholars encouraged human equality and moved toward a more Korean view of Korean history. The Silhak School is thus - well deservedly — credited with helping to create a modern Korea.

Dasan is regarded as one of the most important representative of the Korean Silhak school. As we have seen in the previous sections, he followed a very 
concrete, down-to-earth concept of ethics, which he shared with his fellow Confucians. However, he went on to apply his preference for the specific and concrete to some of the more abstract Confucian virtues.

Dasan rejected the notion that human beings should cultivate an abstract reverence for the unity of the cosmos, or some other hard-to-visualize concept. Nor did he agree with mainstream Neo-Confucians that reverence referred to a general state of mind of the sort we translate today as mindfulness. Instead, he insisted reverence was only true reverence if it was reverence for a specific object. (Baker 2010, 57)

It was precisely this insistence on a specific object of reverence that has led him to his abovementioned belief in a supernatural personality who corresponds to the Western concept of God.

Scholars who write about Dasan as a silhak scholar, i.e. as a realistic and practical thinker, usually refer to his writings on government administration or on land redistribution. However, as Don Baker $(2010,61)$ points out, even if we take into account only his ethical philosophy, we have grounds for calling him a Silhak thinker. His realistic moral psychology, his concrete ethical prescriptions, and his pragmatic theology alone are enough to justify awarding him the proud label of such a scholar.

Therefore, Dasan's political thought which is not only rooted in Confucian philosophy, but also in the theories of Practical Learning, represents an important development of most egalitarian approaches that can be found in the classical Confucian philosophy. Hence, Dasan's thought is also of utmost significance as a theoretical basis for a possible future process of Confucian modernization and democratization.

\section{Conclusion}

Notwithstanding his "Western" orientation, this eighteenth-century Korean Confucian scholar played an important role in the history of the making of East Asian Confucianisms. He created new intellectual trends that helped East Asian Confucians criticize, break through, and think beyond the scope of Zhu Xi's learning. Regarding classical Neo-Confucian doctrines, we can say that in some aspects, Dasan more or less followed their main positions. However, in other respects he certainly developed something innovative and new. Dasan was also well versed in the Confucian thought of the Japanese Classical School, which he 
also criticized while constructing his own system of thought. Thus, he was certainly an innovative philosopher who tried to compose syntheses from several different streams of thought. From a Sinological perspective, the most interesting aspect of his philosophy is certainly to be found in his methodological conception of trinity composed from the two bipolar substances $i$ and $k i$ which are seen as forming the phenomenal world, but are simultaneously transcended by the ultimate source of all existence, the transcendental, monotheist Highest Lord (or Supreme Being), namely Sangje.

This metaphysical basis has also been reflected by and incorporated into his ethical and political thought. In these two scopes of his work, one can observe a great influence of the Silhak School (or the School of Practical Learning, 實學).

Considering all these innovations and the progressive nature of his basic intellectual orientation, it becomes quite clear that Dasan creatively remolded the old to shape the new in the making of Korean and East Asian Confucianisms. Thus, his work is not only significant for a coherent and more comprehensive evaluation of traditional Korean philosophy, but also for developing and investigating new intercultural aspects of Neo-Confucian thought systems.

\section{References}

Baker, Don. 2010. "Practical Ethics and Practical Learning: Tasan's Approach to Moral Cultivation." Acta Koreana 13(2): 47-61.

—. 2013. "Finding God in the Classics: The Theistic Confucianism." Dao 12: 41-55.

Cawley, Kevin N. 2012. "Deconstructing Hegemony: Catholic Texts in Choson's NeoConfucian Context.2 Acta Koreana 15(1): 15-42.

Chang, Wonsuk. "Topical Review of Confucian Philosophy Research in Korea, 2009-2012: Embracing the Ambiguity of Confucianism." Academia.edu. 14. 5 2014. Accessed May 14, 2014.

https://www.academia.edu/5507294/Topical_Review_of_Confucian_Philosophy_Rese arch_in_Korea_2009-2012_Embracing_the_Ambiguity_of_Confucianism

Chung, Chai-sik. 2006. "Between Principle and Situation: Contrasting Styles in the Japanese and Korean Traditions of Moral Culture." Philosophy East and West 65(2): 253-80.

Dasan 茶山 (Jeong Yak-yong 丁若镛). 1974. Yoyudang chonso poyu (Complete Works of Dasan with Annex), 5 Volumes. Kyongin Munhwasa.

Gun, Yoo Tae. 1994. "Metaphysical Grounds of Tasan's Thought." Korea Journal 94(19): 5-19. 
Kwon, Keedon. 2007. "Development in East Asia and a Critique of the Post-Confucian Thesis." Theory and Society 36(1): 55-83.

Lee, Hong-jung. 2003. "Development, Crisis and Asian Values." East Asian Review 15(2): 27-42.

Li Fenggui 李俸珪. 2005. "Han guo xuejie guanyu Chashan xue yanjiude jiaodian 韓國學 界關於茶山學研究的焦點 (Some Central Issues in the Korean Academic Research on Dasan)." In Dongya ruxue yanjiude huigu yu zhanwang 東亞儒學研究的回顧與展 望, edited by Huang, Chun-chieh, 177-217. Taipei: Taida chuban zhongxin.

Ro, Young-chan. 2011. "Ecology and Cosmology:a Korean Neo-Confucian Approach." Acta Koreana 14(2): 113-23.

Tu, Weiming. 2010. "Korean Confucianism from a Sinic Perspective." Acta Koreana 13(2): 5-8.

Yoo, Weon-ki. 2013. "A Research Methodology for Korean Confucianism." Acta Koreana 16(1): 177-97.

Zhu Xi 朱喜. 2000. "Li qi shang 理氣上 (Li and Qi, Part one)." In Zhuzi jin si lu 朱子今思 錄 (Master Zhu's Records for Contemporary Reflection), author Zuqian Li, 13-34. Shanghai: Shanghai guji chuban she. 